Chemical Correlation of Some Late Cenozoic Tuffs of Northern and. Central California by Neutron Activation Analysis of Glass and Comparison with X-Ray Fluorescence Analysis

$\begin{array}{llllll}\text { GEOLOICAL SURVEY PROFESSIONAL PAPER } & 1147\end{array}$
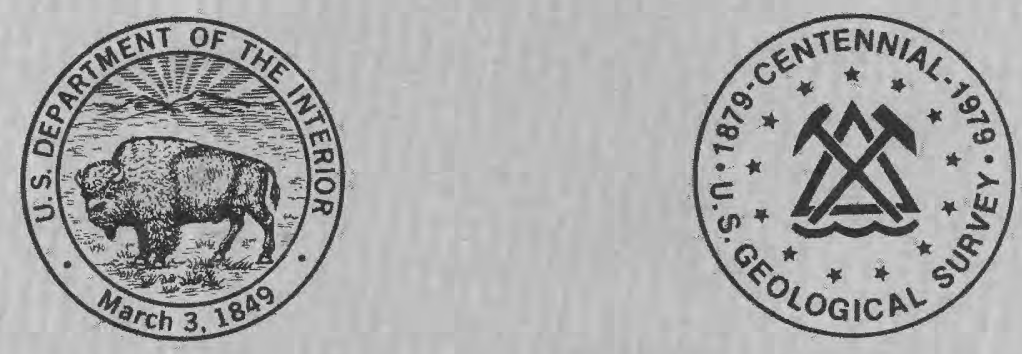
Chemical Correlation of Some Late Cenozoic Tuffs of Northern and Central California by Neutron Activation Analysis of Glass and Comparison with

\section{$X$-Ray Fluorescence Analysis}

By ANDREI M. SARNA-WOJCICKI, HARRY W. BOWMAN, and PAUL C. RUSSELL

GEOLOGICAL SURVEY PROFESSIONAL PAPER 1147

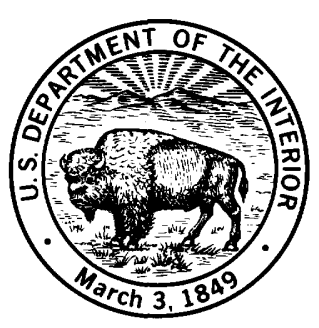




\section{UNITED STATES DEPARTMENT OF THE INTERIOR \\ CECIL D. ANDRUS, Secretary}

\section{GEOLOGICAL SURVEY}

H. William Menard, Director

Library of Congress Catalog-card No. 79-600136

For sale by the Superintendent of Documents, U.S. Government Printing Office

Washington, D.C. 20402

Stock No. 024-001-03219-8 


\section{CONTENTS}

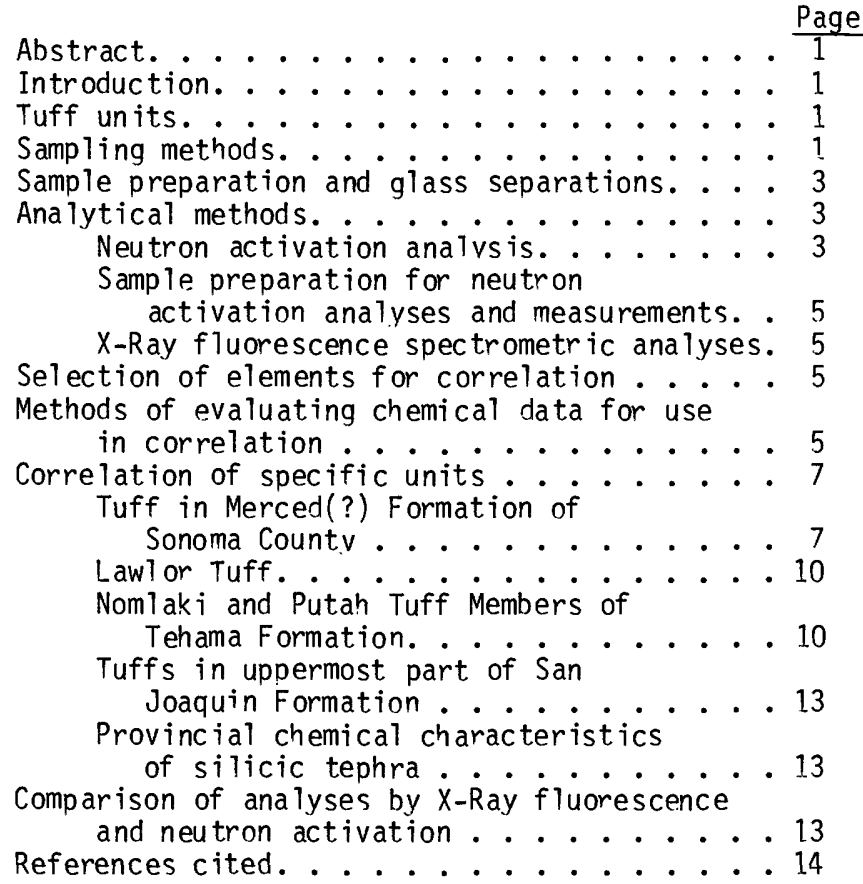

\section{ILLUSTRATIONS}

Figure 1. Generalized geologic map showing location of samples, central Coast Ranges, California. . . 2

2. Histograms showing ratios of element concentration in glass samples to USGS standard rock $G-1$ and differences between ratios of selected sample pairs....... 6

3. Diagram summarizing correlation of late Cenozoic tuffs based on neutron activation analys is of glass.......... 11

4. Similarity coefficient dendrogram. . 12

\section{TABLES}

Table 1. Age of tuff units studied. ... 4

?. Analyses of USGS standard rock G-2 by neutron activation and $X$-ray fluorescence. . . . . 3

3. Neutron activation analyses of glass of tuffs. . . . . 8

4. Chemical analvses hy X-ray fluorescence. ...... 14 
. 


\title{
Chemical Correlation of Some Late Cenozoic Tuffs of Northern and Central California by Neutron Activation Analysis of Glass and Comparison with X-Ray Fluorescence Analysis
}

\author{
By Andrei M. Sarna-Wojcicki, Harry W. Bowman, and Paul C. Russell
}

\section{ABSTRACT}

Glasses separated from several dacitic and rhyolitic late Cenozoic tuffs of northern and central California were analyzed by neutron activation for more than 43 elemental abundances. Eighteen elements--scandium, manganese, iron, zinc, rubidium, cesium, barium, lanthanum, cerium, samarium, europium, terbium, dysprosium, ytterbium, hafnium, tantalum, thorium and uranium--were selected as most suitable for purposes of chemical correlation on the bas is of their natural variability in silicic tuffs and the precision obtainable in analvs is. Stratigraphic relations between tuffs and replicate chemical analyses on individual tuffs make it possible to calibrate a quantitative parameter, the similarity coefficient, which indicates the degree of correlation for the tuffs studied. The highest similarity coefficient (0.99) was obtained for analyses of two tuffs (potassium-argon dated at about 6.0 m.y.) exposed in the Merced(?) and Petaluma Formations of Sonoma County, which represent different paleoenvironments, shallow-water marine and fresh water or brackish marine, respectively. Correlation of these formations on the bas is of criteria other than tephrochronoloqy would be difficult. Results of neutron activation analys is in general confirm earlier correlations made on the basis of analys is by $X-r a y$ fluorescence but also make it possible to resolve small compositional differences between chemically similar tuffs in stratigraphic proximity. The Lawlor Tuff (potassium-argon dated at about $4.0 \mathrm{m.y.}$ ) is identified at two new localities: in a core sample obtained from a bore hole east of Suisun Bay, and from the Kettleman Hills of western San Joaquin Valley. This identification permits correlation of the uppermost part of the marine Etchegoin Formation in the San Joaquin Valley with the continental Livermore Gravels of Clark, the Tassajara Formation, and the upper part of the Sonoma Volcanics in the central Coast Ranges of California. A younger tuff near the top of the marine San Joaquin Formation in the Kettleman Hills has been identified at both new localities.

\section{INTRODUCTION}

Within the past 14 years, a number of papers have been published on chemical correlation of volcanic ashes and tuffs (Czamanske and Porter, 1965: Jack and others, 1968; Lajoie and Carmichael, 1968; Jack and Carmichael, 1968; Izett and others, 1970; Borchardt and others, 1972; Randle and others, 1971; Dudas and others, 1973; Bartow and others, 1973; see also Westgate and Gold, 1974). The method has been shown to work well using a variety of analytical techniques and a number of elements. Most workers, however, have focused their attention on specific stratigraphic problems or the development of a particular analytical method. To this time, there has not been any

$1_{\text {Lawrence Berkeley }}$ California, Berkeley. comparative evaluation of the different methods--which analytical method and what combination of elements work best to solve a particular problem. Nor has there been much statistical work done on the natural chemical variability of tephra--what differences exist within individual eruptive units, between eruptive units, and between units erupted from different volcanic provinces. Such studies can make correlations more definitive by defining the spectrum of compositional types, and they can help standardize analyses so that data collected by different workers can be used in making new correlations.

The present study has three purposes: to determine which elements are most suitable for chemical correlation using neutron activation analys is to calibrate quantitative parameters (similarity coefficients) that show correlation and provincial relations between tuffs, and to test by neutron activaition analyses correlations made previously on the basis of $X$-ray fluorescence spectrometry (SarnaWojcicki, 1976).

Acknowledgments.--We are grateful to Douglas Hamilton of Earth Sciences Associates who provided core samples from the Collinsville area used in this study and to John Obradovich for providing information on tuffs in the Kettleman Hills.

\section{TUFF UNITS}

Tuff units studied were, from youngest to oldest: two thin tuffs in the uppermost part of the San Joaquin Formation, exposed in the Kettleman Hills of western San Joaquin Valley (samples 2 and 3) and the uppermost tuff in subsurface near Collinsville, east of Suisun Bay (sample 1); the Nomlaki Tuff Member of the Tehama Formation of northwestern Sacramento Valley (samples 4-9); the Putah Tuff Member (samples 10-15) of the Tehama Formation of southwestern Sacramento Valley, approximately the same age as the Nomlaki; the upper tuff in Livermore Gravels of Clark (1930) south of Livermore Valley (sample 16); the Lawlor Tuff, (samples 17-34); the tuff in the Merced(?) Formation of Sonoma County (samples 35-42); and the tuff above the Neroly Formation and below the Contra Costa Costa Group near Lafayette (samples 43, 44). Sample localities for these tuffs are shown in figure 1; their ages, stratigraphic positions, and earlier sources are summarized in table 1 . Results of neutron activation analyses of glass samples of these tuffs are given in table 3 , and resulis of $x$-ray fluorescence analyses are given in table 4 . Note that some samples are analyzed only by neutron activation or X-ray fluorescence analys is and consequently are listed in only one of the two tables.

\section{SAMPLING METHODS}

About $500 \mathrm{~g}$ of sample was collected from tuff outcrops. At some localities, several samples were collected vertically and laterally in each unit to test for compositional variations. At several localities, where two or more units are exposed in a stratigraphic sequence (for example, 1, 2, 15, 30), it was possible to test for compositional differences 


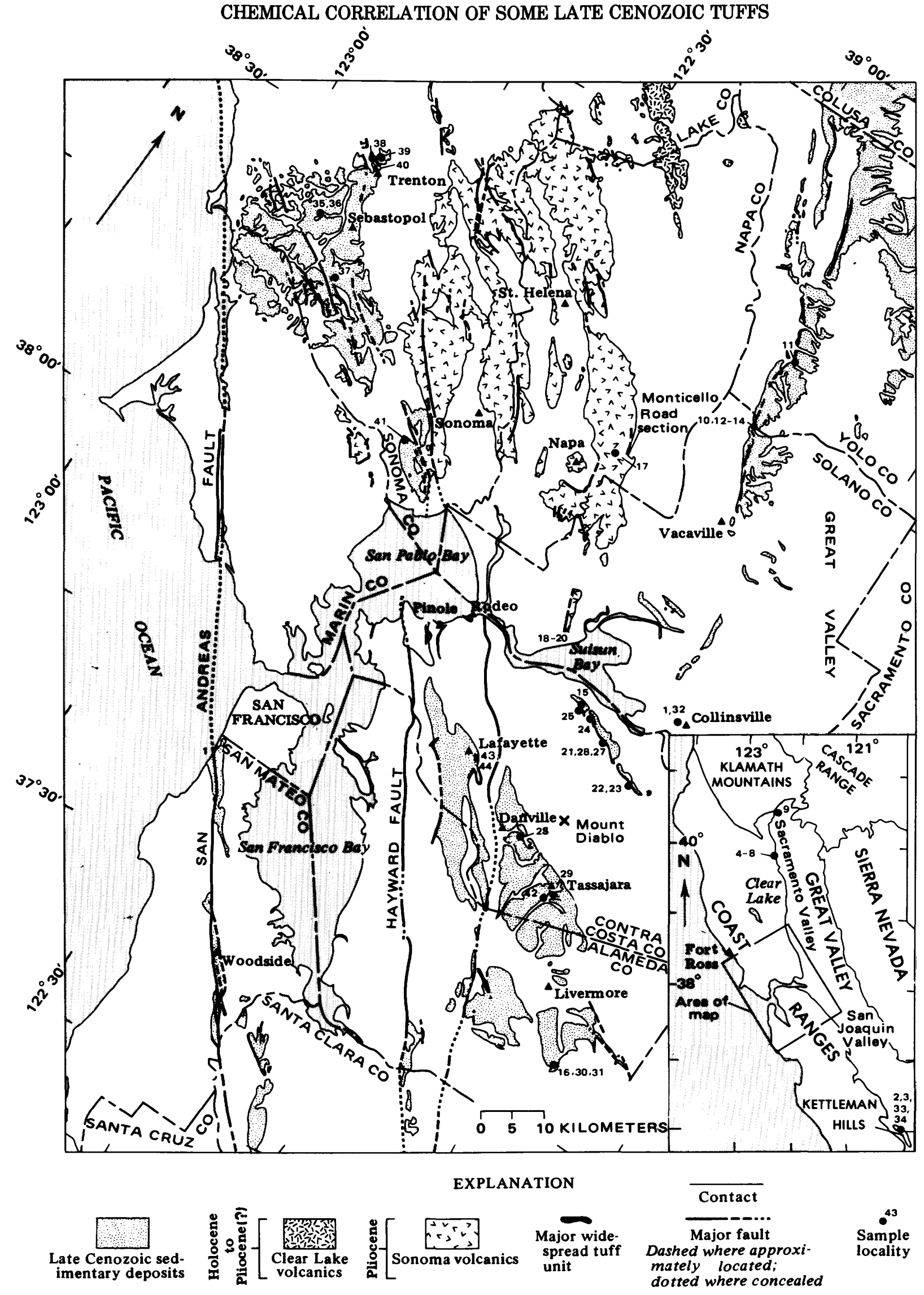


between tuffs of different ages. Replicate analyses of samples from individual units, together with analyses from multiple units in stratigraphic sequence, provide control for calibrating quantitative parameters such as the similarity coefficient of Borchardt, Aruscavage, and Millard (1972) that indicate correlation or its absence where stratigraphic control is not available.

\section{SAMPLE PREPARATION AND GLASS SEPARATIONS}

Previous experience has shown that results of chemical analyses are markedly affected by the quality of glass separations (Sarna-Wojcicki, 1971, 1976). The presence of phenocryst, microlite, or lithic particles in qlass separates can produce variations in trace-element composition owing to enrichment or depletion of many elements in these particles relative to glass ( $f$ or example, concentrations of strontium and europium in plagioclase feldspar and iron, titanium, scandium, manganese, and zinc in amphiboles, pyroxenes and opaque minerals). Contamination bv groundwater may cause similar variations in composition, such as in concentrations of strontium and barium as carbonates. Such variations are difficult or impossible to distinguish from differences due solelv to variations in glass composition within and between individual tuff units. For this reason, glass separation is a critical laboratory procedure that requires great care.

Samples were disaggregated by hand or crushed in a mullite rotary crusher or mortar and sieved in plastic sieves with nylon screens. The 100-200-mesh size fraction was treated with 10-percent reagent grade $\mathrm{HCl}$, rinsed several times in distilled water, etched wih 5-percent reagent grade HF, rinsed several times again, vibrated in an uitra-sonic probe, dried, and resieved. The sample was then separated in a Frantz magnetic separator and in acetone-bromoform and acetone-methylene iodide liquid mixtures utilizing a density-gradient column. For some samples, these procedures were repeated several times before a satisfactory separation was obtained.

${ }^{1}$ Initially, the 60-120-mesh size fraction was used; the smaller fraction was later chosen to reduce the number of glass shards containing phenocrysts and microlites. Size fractions finer than 200 mesh are difficult to work with owing to clumping during magnetic and heavy-liquid separations. The openings in nylon screens are somewhat smaller than those in equivalent mesh brass and stainless steel screens.

Figure 1.--Generalized geologic map showing location of samples, central Coast Ranges, California. Geology from Strand and Koenig (1965), Koenig (1963), Rogers (1966), Jennings and Burnett (1961), and Ross Wagner (written cormun., 1974). Modified from Sarna-Wojcicki (1976).

\section{ANALYTICAL METHODS NEUTRON ACTIVATION ANALYSIS}

When rock samples are irradiated with neutrons, many radioactive species are formed, and the mixture produces very complex gamma-ray spectra. The elemental sensitivities are directly related to the nuclear cross sections, and isotopic abundances inversely to radioactive half-lives, and varv considerably from element to element. Detailed computer analys is of these spectra can give very precise information on the abundances of a large number of elements. Using this method, we test for more than 50 elements, usually detect less than 40 , and can actually use about 18 to 20 elements in correlation studies such as these.

Precision and sampling errors are tested at frequent intervals by analyzing a very homogeneous obsidian from Central America. The elemental precision for the 16 most precisely measured elements in this material varied from less than 1 percent to slightly more than 4 percent and resulted in an average standard deviation of 1.5 percent.

The accuracies here are controlled primarily by the uncertainties in chemical compositon of our composite standard, a fired clay called "standard pottery." Many of the analytical procedures used in this study were originally developed during archeological studies of pottery types and their distributions in the Middle East (Perlman and Asaro, 1969). By our analysis of USGS standard rock G-2 by neutron activation analysis, using standard pottery as

$$
\text { Tahle 2.--Analyses of USGS standard rock G-2 by neutron }
$$

[Data for XRF analyses from Carmichael, Hempe1, and Jack 11968).

\begin{tabular}{|c|c|c|c|}
\hline Element & $\begin{array}{c}\text { Average } \\
\text { concentration } \\
\text { (Flanagan, 1969) }\end{array}$ & $\begin{array}{l}\text { Neutron } \\
\text { activation } \\
\text { (this study) }\end{array}$ & $\begin{array}{c}\text { X-ray fluorescence } \\
\text { (Carmichae } 1 \text { and others, } \\
1968 \text { ) }\end{array}$ \\
\hline Sc-....- & 3.9 & $3.70 \pm 0.07$ & -- \\
\hline Ti-_..... & 2780 & -- & $2930 \pm 3$ \\
\hline$M n-\cdots-\cdots$ & 260 & $250 \pm 7$ & $280 \pm \overline{5}$ \\
\hline Fe--.-.-. & 1.85 & $1.90 \pm 0.04$ & $1.84 \pm 0.02$ \\
\hline $\mathrm{Zn}-\ldots$ & 85 & $97 \pm 15$ & $80 \pm 2$ \\
\hline $\mathrm{Rb}--\cdots$ & 168 & $18 \overline{5} \pm 20$ & $175 \pm ?$ \\
\hline Sr-.--.- & 479 & -- & $465 \pm 2$ \\
\hline Y & 12 & -- & $10 \pm ?$ \\
\hline Zr-.-.--- & 300 & -- & $3 ? 0 \pm 0$ \\
\hline Cs--.--.- & 1.4 & $1.5 \pm 0.2$ & -- \\
\hline $\mathrm{Ba}-\ldots$ & 1870 & $1900 \pm 90$ & $2030 \pm 20$ \\
\hline La----_-_ & 96 & $91 \pm 2$ & $110 \pm 10$ \\
\hline Ce------- & 150 & $165 \pm 5$ & $175 \pm 10$ \\
\hline Sm-n..... & 7.3 & $7.0 \pm 1$ & $10 \pm 5$ \\
\hline Eu------- & 1.5 & $1.36 \pm 0.05$ & $-\infty$ \\
\hline Tb-- - - - & .54 & $.5 \pm 0.1$ & --- \\
\hline Dy---- & 2.6 & $2.5 \pm 0 . ?$ & -- \\
\hline$Y \mathrm{~b}-\cdots$ & .88 & $.84 \pm 0.03$ & -. - \\
\hline Hf - - - - & 7.35 & $8.4 \pm 0.7$ & -- \\
\hline Ta-----.- & .01 & $.74 \pm 0.02$ & --- \\
\hline Th-n-.-- & 24.2 & $25.2 \pm 0.9$ & $30 \pm 5$ \\
\hline U-.-....- & 2.0 & $2.0 \pm 0.1$ & -- \\
\hline
\end{tabular}
Iron in percent; other elements in ppm.] 


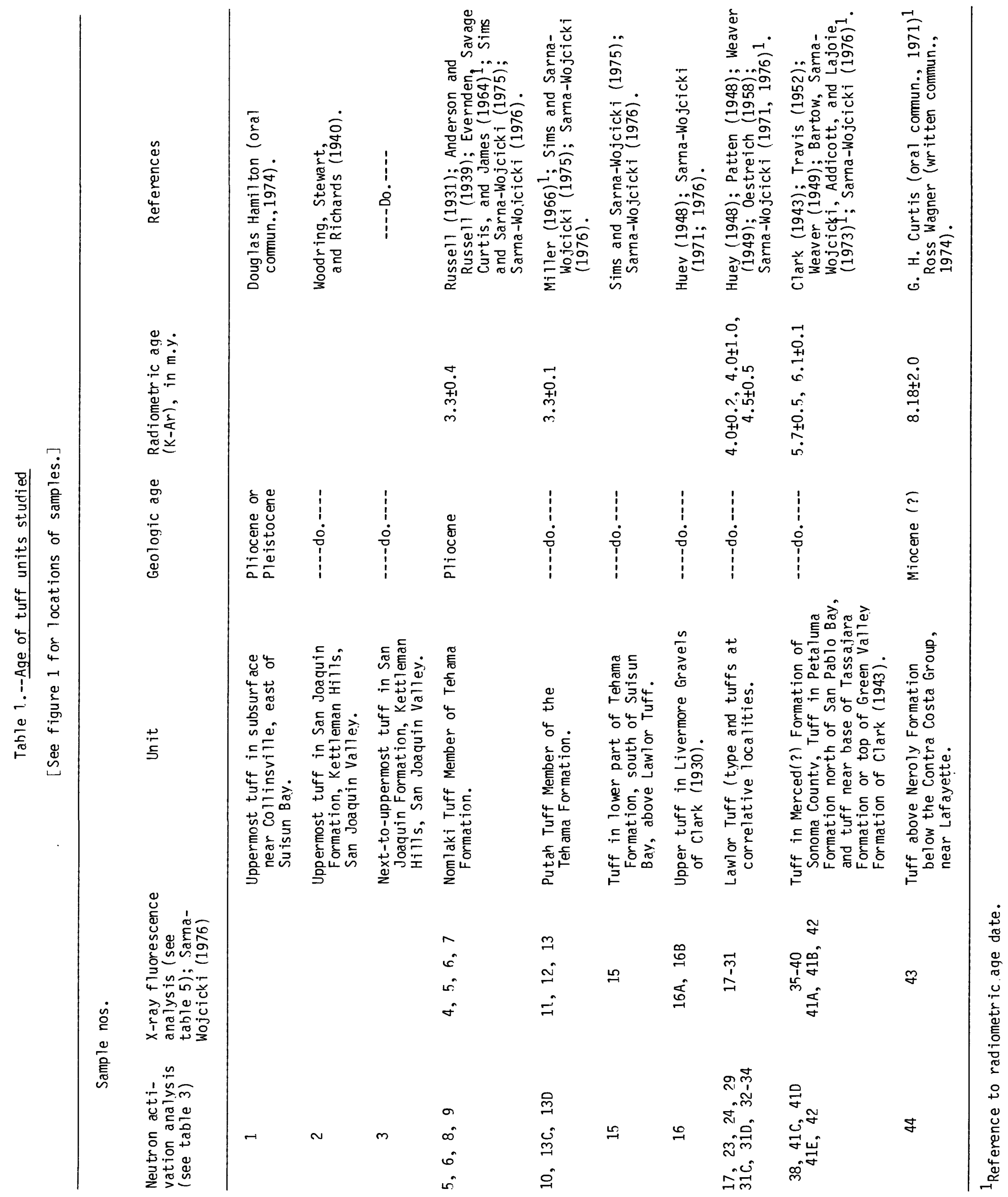


the reference standard (table 2), other data presented here can be normalized to USGS preferred abundances of G-2.

Further information on the analytical method, including an explanation of the accuracies attainable, is given in Bowman, Asaro, and Perlman (1973).

\section{SAMPLE PREPARATION FOR NEUTRON \\ ACTIVATION ANALYSES AND MEASUREMENTS}

Glass separates were ground to a powder and 100 $\mathrm{mg}$ mixed with $50 \mathrm{mg}$ of cellulose binder and pressed into small pills. The pills were placed on edge in a radial array along with two identical standards and irradiated in the central thimble of the Berkeley Triga reactor for 18 minutes at $1.7 \times 10^{12} \mathrm{~ns} / \mathrm{cm}^{2}$ later for 8 hours at $3 \times 10^{13} \mathrm{~ns} / \mathrm{cm}^{2}$. The two standards were placed opposite each other, and the sample capsules rotated continuously during each bombardment.

Six different measurements were made on each unknown and standard set using various gamma-ray counting systems. For most analyses, samples were handled by automatic sample-changing equipment and the data, counting periods, dead-time counting rates, date, and time of the analysis recorded on magnetic tape. Computer progams determined the elemental abundances and errors by comparing the unknowns and the standard gamma-ray spectral data. Checks between individual analyses were made, as some elements were determined several times.

\section{X-RAY FLUORESCENCE SPECTROMETRIC ANALYSES}

Concentrations of trace and minor elements in glass separates were determined earlier (SarnaWojcicki, 1976) by means of a Norelco Universal Vacuum Spectrograph ${ }^{2}$ using the analytical procedures described by Jack and Carmichael (1968). A detailed description of analytical methods is given in SarnaWojcicki (1971, 1976).

Glass samples were mixed with 20 percent by weight fibrous cellulose binder and pressed into 3.2$\mathrm{cm}$-diameter discs in a hydraulic press at pressures of about $2500 \mathrm{~kg} / \mathrm{cm}^{2}$. The standards were similarly prepared in order to provide uniform surfaces for both sample and standard. Glass separates were then analyzed for titanium, manganese, iron, nickel, copper, zinc, gallium, rubidium, strontium, yttrium, zirconium, niobium, and barium. The position for each of these elements was calibrated with pure element standards, (for example $\mathrm{RbCl}$ for rubidium); element concentrations were determined by fixed-time counts at fixed $2 \theta$ positions. Additional counts were made at adjoining $2 \theta$ positions to determine the shape and intensity of the background curve. Standards used were G-1 and G-2 for all elements except gallium, zinc, copper, and nickel, for which $W-1$ was used (Fleisher, 1969; Flanagan, 1969).

${ }^{2}$ Any use of trade names is for descriptive purposes only and does not constitute endorsement of these products by the U.S. Geological Survey.

\section{SELECTION OF ELEMENTS FOR CORRELATION}

For the purpose of correlation, elements were selected on the basis of their variability within and between tuff units as well as according to the precision attainable for each element in neutron activation analysis. Independent stratigraphic evidence and radiometric age determinations make it possible to select the elements on the basis of their natural abundance and variability in tuffs and limitations of the analytical procedures used.

Eighteen elements--scandium, manganese, iron, zinc, rubidium, cesium, barium, lanthanum, cerium, samarium, europium, terbium, dysprosium, ytterbium, hafnium, tantalum, thorium, and uranium--were particularly useful in chemical correlation of silicic tephra in this study (table 3 ).

Six elements for which the analytical precision was about 12 percent or better--aluminum, sodium, potassium, cobalt, lutecium, and neodymium--were not included in calculations of similarity coefficients (below) because they do not provide adequate resolution for tephra units of different ages. Analytical error for the remaining 19 elements-magnesium, chlorine, calcium, titanium, vanadium, chromium, nicke1, copper, gallium, arsenic, strontium, silver, indium, tin, antimony, tungsten, iridium, gold, and mercury--was greater than 12 percent of their average concentration in these silicic tuffs. of 13 elements analyzed by X-ray fluorescence in the previous study (Sarna-Wojcicki, 1976), 8 were used in correlation of tuff units: titanium, manganese, iron, zinc, rubidium, strontium, zirconium, and barium. The five elements not included were copper, nickel, gallium, yttrium, and niobium. Because some elements--manganese, iron, zinc, rubidium, and barium--were analyzed by both methods, it was possible to compare concentrations determined on splits of the same samples and to derive conversion factors from neutron activation to $\mathrm{X}-\mathrm{r}$ ay fluorescence analyses by least-squares plots.

\section{METHODS OF EVALUATING CHEMICAL}

\section{DATA FOR USE IN CORRELATION}

The degree of correlation between samples based on results of neutron activation analysis was determined graphically and numerically. First, concentrations of each of the eighteen elements used in correlation were ratined to recommended concentrations of the same elements in USGS standard rock G-1, and histograms comparing sample pairs were made (fig.2). Second, similarity coefficients have been calculated for everv sample pair. This coefficient (Borchardt and others, 1972) is given by: 
16

15

RATIO OF ELEMENT CONCENTRATIONS

IN GLASS SAMPLES TO G-1

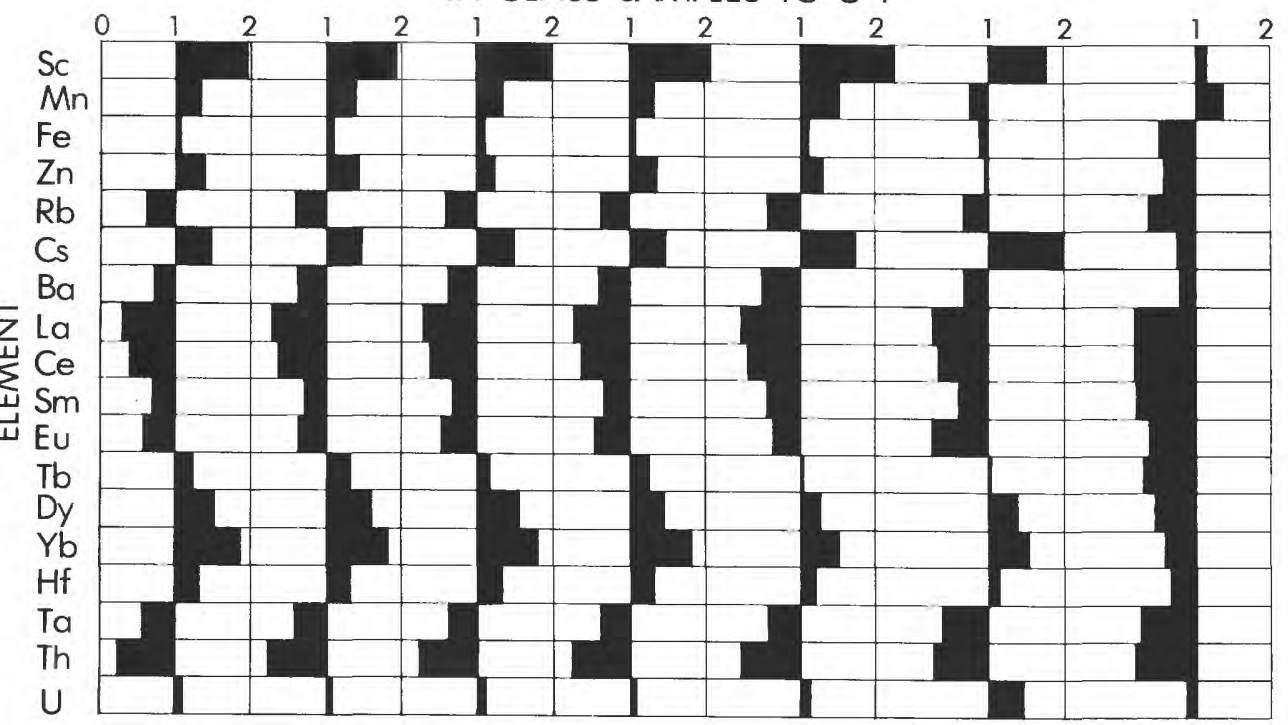

5
23-24 24-3IC 23-29 16-3IC 15-23 5-3IC DIFFERENCE BETWEEN RATIOS OF SELECTED SAMPLE PAIRS

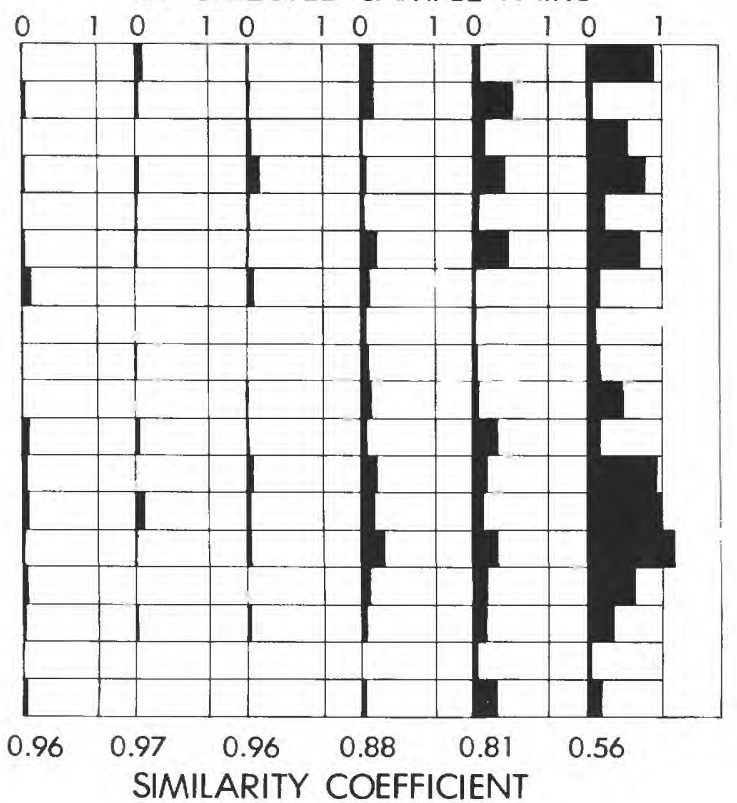

Figure 2.--Ratios of concentrations of elements in samples of volcanic glass to concentrations of the same elements in USGS standard rock G-1 are shown on the left side of the diagram. Absolute values of the differences of these ratios for selected sample pairs are shown on the right side of the diagram. Corresponding values of the similarity coefficient for these pairs are given below the right side of the diagram, beneath the corresponding sample pairs. Recommended values of G-1 (Fleisher, 1969) are used for all elements except for Cs, Tb, and Yb, to which values of 6,1 , and 2.5 parts per million, respectivelv, were assigned to avoid high ratios. Samples 23 and 24 are from the Lawlor Tuff. Samples 29 and $31 \mathrm{C}$ are correlated with the Lawlor Tuff on the bas is of glass chemistry and other criteria (see text). Samble 16 is from a tuff which closely overlies the tuff containing sample 31C. Sample 15 is from a tuff correlated with the Putah Tuff Member of the-Tehama Formation (SarnaWojcicki, 1976), which also overlies the Lawlor Tuff, but is considerably younger than both the Lawlor Tuff and the tuff overlying it (sample 16). All samples are from tuffs which were erupted in the Sonoma volcanic field, except for sample 5, from the Nom?aki Tuff Member of the Tehama Formation, which was erupted from the southern Cascade Range volcanic field.

$$
d(\text { A.B. })=\frac{\stackrel{\sum_{i}^{n}}{=} R_{i}}{n},
$$

where

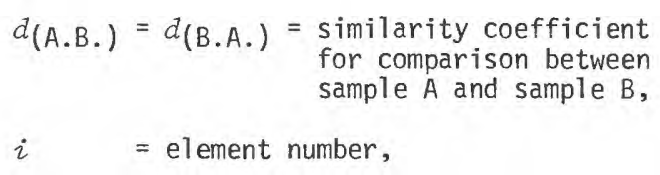

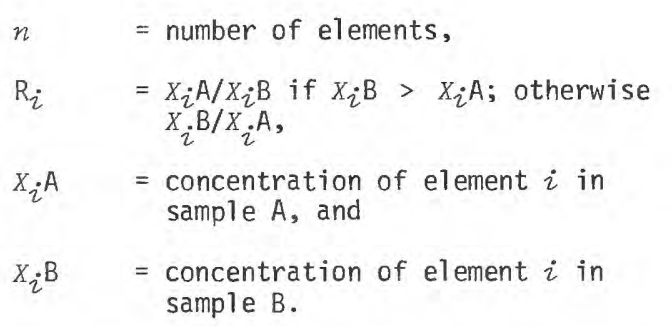


The value of the similarity coefficient for a chemically identical sample pair is 1 . In practice, the value of the coefficient for replicate analyses of samples from a single outcrop, or of splits of the same sample, ranges from about 0.93 to 0.99 owing to inhomogeneities in the glass, slight variations in degree of separation of the glass, or analytical errors. For some of the earlier analyses of samples from the same outcrop, values of this coefficient are as low as 0.90 , owing perhaps to incomplete separation of crystalline material from the glass. Values of similarity coefficients for tuff samples of demonstrably different age (for instance, tuffs superposed within a continuously exposed section) range from 0.45 to a high of 0.88 . Since the ranges of replicate analyses from a single tuff generally do not overlap with those of tuffs of different ages, similarity coefficients can be used as quantitative guides to indicate correlation or its absence where stratigraphic control is not available.

As an example, let us consider the correlation of the Lawlor Tuff on the basis of its glass chemistry. Tuff samples taken from two outcrops of the Lawlor Tuff between which the tuff is continuously exposed (samples 23 and 24) show minor differences and a high similarity coefficient of 0.96 (fig.2). A comparison of samples 23 and 29 reveals similar minor differences and the same similarity coefficient of 0.96 is calculated, although the tuff in this instance is not continuousiy exposed between these two localities (figs. 1 and 2). Since samples 23 and 29 are similar to the same extent as samples 23 and 24 , they are here considered correlative and support an earlier correlation based on X-ray fluorescence analysis and petrographic criteria of the same samples (SarnaWojcicki, 1976). Independent evidence supporting this correlation comes from potassium-argon ages of the tuffs at localities 23 and $29(4.0 \pm 0.2$, and $4.0 \pm 1.0$ m.y., respectively, Sarna-Wojcicki, 1976).

The Lawlor Tuff is also found further south in Livermore Valley, at locality 31 . Sample 31 compares closely with the aforementioned Lawlor Tuff samples, the similarity coefficients for these comparisons being $0.97,0.97$ and 0.96 . At locality 31 , the Lawlor Tuff is overlain by a chemically and petrographically similar tuff (sample 16, table 3 and figs. 2 and 3 ). The similarity coefficient comparing the two superposed tuffs is 0.88. Analyses such as these on a number of superposed ashes and tuffs, combined with replicate analyses from individual units, have permitted calibration of similarity coefficients and make them a useful tool in evaluating tephrochronological data.

Within our experience, however, similarity coefficients for some tuff samples of different radiometric age erupted within the same volcanic province (for instance, the Putah Tuff Member of the Tehama Formation, potassium-argon dated at $3.3 \pm 0.2$ m.y., and the tuff in the Merced(?) Formation of Sonoma County, potassium-argon dated at about 5.9 m.y.; see table 1) can be as high as 0.90 . Consequently, similarity coefficients within the range 0.89-0.92 represent an interval of uncertainty and are not by themselves considered to be conclusive evidence of correlation or its absence.

Since similarity coefficients of tuffs of different ages erupted within a single volcanic province or field (about 0.65-0.88) are generally lower than those of replicate analyses from the same unit but are higher than those of tuffs erupted from different volcanic fields (about 0.45-0.65), they provide a criterion for determining tuff or ash provenance. For instance, samples 5 and $31 \mathrm{C}$ (fig. 2) were erupted from different volcanic provinces. Their different origins are reflected in the glass chemistry of these two tuffs. Samples. 15, 16, and samples of the Lawlor Tuff are from tuffs erupted from the same volcanic province, the Sonoma volcanic field, and bear a strong family resemblance to each other, a reflection of the ir common genesis (fig. 2).

The ranges of similarity coefficients given here apply only to units and volcanic areas studied by the neutron activation analytical method for the 18 elements used in the comparison procedure. Somewhat different values will be obtained if other units, analytical methods, or elements are used.

A matrix comparing values of similarity coefficients for all sample pairs in the study group was calculated. The relation of all analyzed samples with respect to the similarity coefficient is shown by a dendrogram (fig. 4) based on maximum individual values of similarity coefficients for sample pairs and maximum averages of coefficients for sample groups.

\section{CORRELATION OF SPECIFIC UNITS}

A summary of correlations documented in this study is given in a correlation chart, fig. 4. Discussion of correlation of specific units, from oldest to youngest, follows.

\section{TUFF IN MERCED(?) FORMATION OF SONOMA COUNTY}

Neutron activation analyses presented in this study confirm earlier correlations (Sarna-Wojcicki, 1976) of the tuff in the marine Merced(?) Formation of Sonoma county (10c. 38) with the tuff in the estuarine(?) Petaluma Formation near Sears Point (10c. 41 , samples $41 C, D$, and $E$ ), and the tuff near the base of the continental Tassajara Formation or the top of the continental Green Valley Formation of Clark (1943) (10c. 42) (figs. 1 and 3). Ten similarity coefficients obtained from comparison of glass chemistry of samples pair range from 0.94 to 0.99 (fig.4) with an average value of 0.96 . Samples $41 C$, $D$, and $E$, replicate analyses of samples from a single outcrop in the Petaluma Formation, correlate at values of $0.95,0.95$, and 0.98 , which also average 0.96 . The highest similarity coefficient obtained in this study $(0.99$ for samples 38 and 41E, Fig. 4) is for tuff exposed at localities more than $60 \mathrm{~km}$ apart in two different formations representing two different depositional environments and facies, and consequently different faunal assemblages. Contact relations between the two formations are nowhere exposed, being either severed by faults or covered by younger alluvium. 


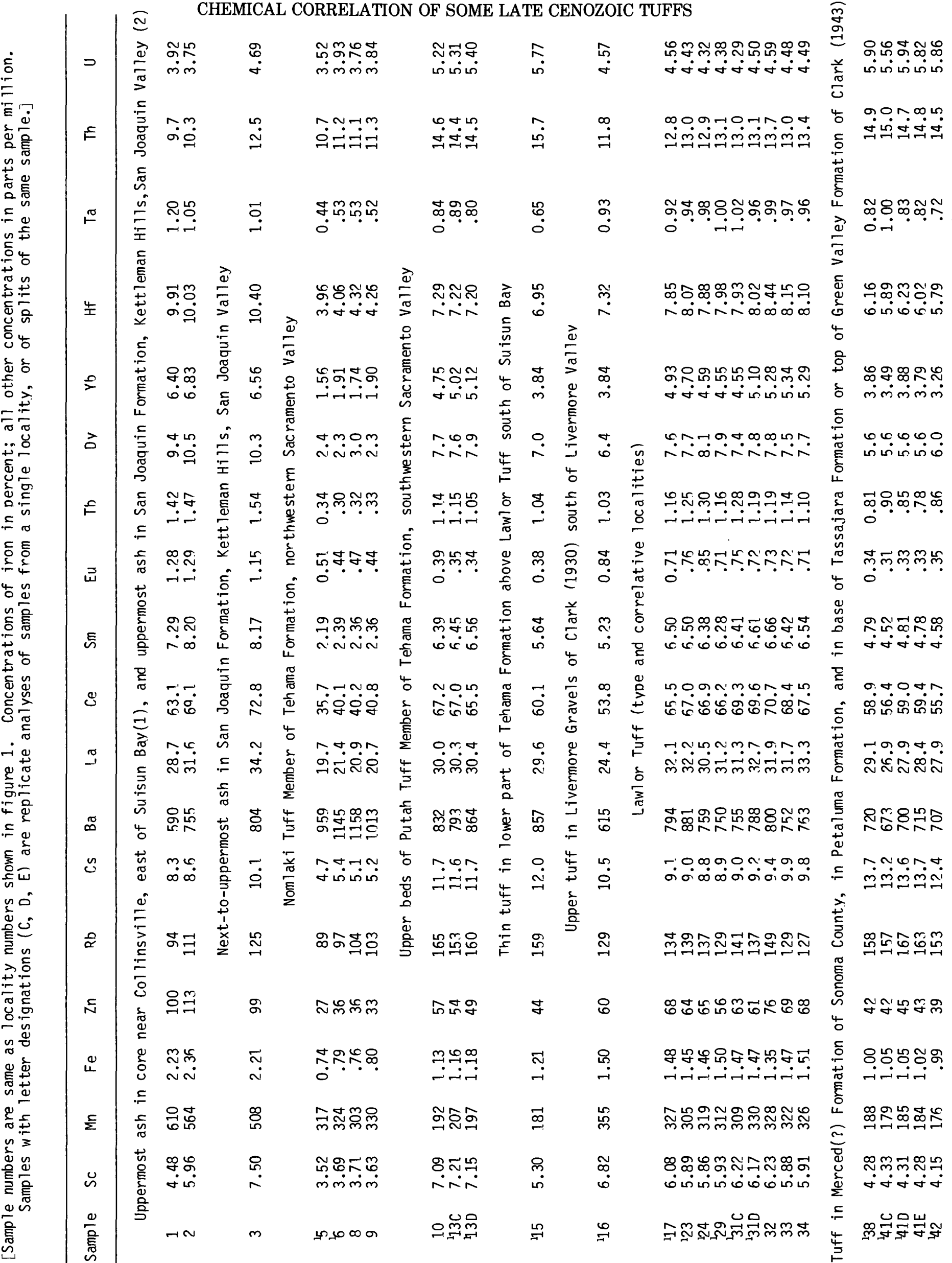




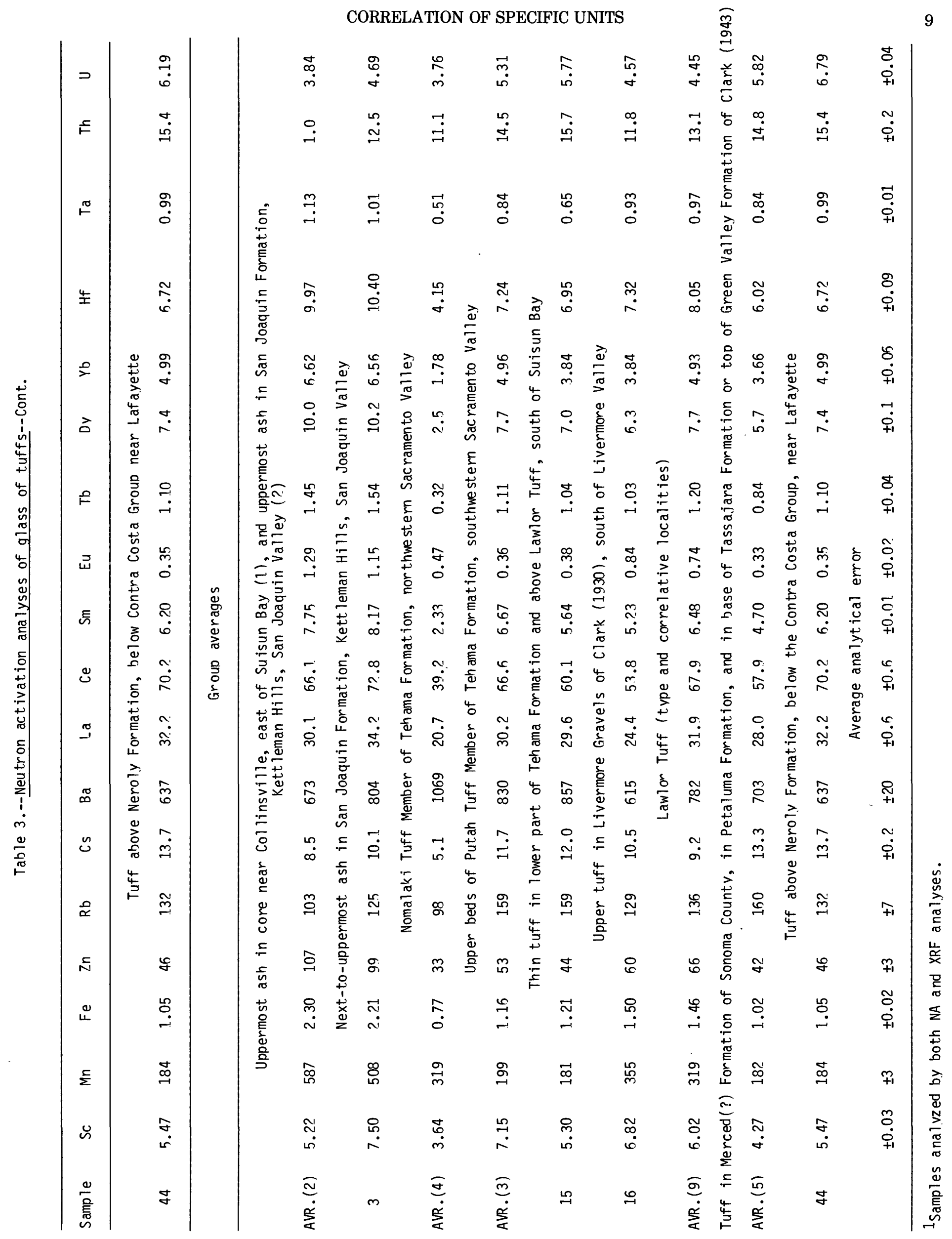


The tuff overlying the Neroly Formation and underlying the Contra Costa Group near the town of Lafayette at locality 44 (fig. 1), previously tentatively correlated with the tuff in the Merced(?) Formation of Sonoma County (Sarna-Wojcicki, 1976), does not correlate with that tuff or with any other unit in this study. Chemically, the tuff at locality 44 is most similar to the Putah Tuff Member of the Tehama Formation (similarity coefficients of 0.89 to 0.91 ) and the tuff in the Merced(?) Formation of Sonoma County (similarity coefficients of 0.85 to 0.88), (fig. 4). Stratigraphic and radiometric age data (table 1, fig. 3) together with earlier petrographic and $X-r a y$ fluorescence data (SarnaWojcicki, 1976), suggest that this tuff is as old or older than the tuff in the Merced(?) and much older than the Putah. Correlation of the tuff at locality 44 remains uncertain.

\section{LAWLOR TUFF}

As mentioned earlier, sample 31 ( $C$ and $D$ ), from the lower tuff in the Livermore Gravels of Clark (1930) south of Livermore Valley (fig. 1), is correlated with samples 23,24 , and 29 , the similarity coefficients being $0.97,0.97$ and 0.96 , respectively (fig. 4). A potassium-argon age of $4.5 \pm 0.5 \mathrm{~m} . y$. on the tuff at sample locality 31 compares closely with dates obtained at localities 23 and $29(4.0 \pm 0.2$ and $4.0 \pm 1.0$ m.y.).

A light-gray, water-deposited, watertransported(?) fine-grained vitric tuff (sample locs. 33 and 34) near the uppermost part of the Etchegoin Formation in the Kettleman Hills of western San Joaquin Valley (Woodring and others, 1940) is here correlated with the Lawlor Tuff (figs. 1 and 3 ). Trace- and minor-element chemistry of the glass in this tuff is essentially identical to that of the Lawlor and its other correlatives. Similarity coefficients between samples of the tuff in the Etchegoin Formation and samples of the Lawlor Tuff and its correlatives range from 0.94 to 0.97 with an average of 0.96 ( $f$ ig 4 ).

A gray pumice-lapilli tuff, the middle one of three obtained from an exploratory bore hole near Collinsville east of Suisun Bay at a depth of $205 \mathrm{~m}$ (courtesy of Douglas Hamilton, Earth Science Associates), also correlates well with the Lawlor Tuff and its other correlatives. Similarity coefficients between the tuff from Collinsville (sample 32 ) and the Lawlor Tuff and other correlatives range from 0.93 to 0.96 , with an average of 0.95 .

In summary, the chemical data presented here make it possible temporally to correlate the uppermost part of the marine Etchegoin Formation of western San Joaquin Valley (locs. 33, 34) with certain formations in the central Coast Ranges: basal(?) lacustrine or alluvial deposits of the Livermore Gravels of Clark (1930) (loc. 31); alluvial gravels of the Tassajara Formation (10c. 29); the Lawlor Tuff south of Suisun Bay, which overlies the Neroly Formation and is overlain by the Tehama Formation (Sims and SarnaWojcicki, 1975) (locs. 23 and 24); unnamed alluvium in the subsurface near Collinsville, east of Suisun Bay (1oc. 32); and the upper part of the Sonoma Volcanics, north of San Pablo and Suisun Bays (10c. 17) (fig. 3).

These correlations illustrate advantage of the correlation method employed here. Samples 17, 23, 24, and 29 are from an ash-flow facies, sample 31 is from a water-laid lacustrine facies, and samples 33 and 34 are from a water-laid marine facies; all of these are now identified as the Lawlor Tuff. It would be difficult or impossible to make these correlations on the basis of field observations or paleontologic criteria alone.

At a locality south of Livermore, two tuffs (sample 16, is from the upper tuff, and samples $31, \mathrm{C}$ and $D$, from the lower tuff) separated by about $8 \mathrm{~m}$ of tuffaceous deposits, are difficult to distinguish on the basis of $X$-ray fluorescence analysis or petrographic data (Sarna-Wojcicki, 1976) but are clearly distinguishable by chemical differences determined by neutron activation (table 3; figs. 2, 4). The similarity coefficients between sample 16 and 31 ( $C$ and D) are 0.88 and 0.88 . The average of all similarity coefficients between sample 16 and samples of the Lawlor Tuff is also 0.88 .

\section{NOMLAKI AND PUTAH TUFF MEMBERS}

\section{OF TEHAMA FORMATION}

Three samples of the Nomlaki Tuff Member analyzed by neutron activation, samples 5,6 , and 8 , are from a single outcrop at its type locality in the former Nomlaki Indian Reservation, but from different stratigraphic positions in the unit. Sample 9 is from a locality about $50 \mathrm{~km}$ farther north (fig. 1, inset map). Samples 6,8 , and 9 are very similar chemically (similarity coefficients of $0.95,0.95$, and 0.97 , fig. 4). Sample 5, compared with 6, 8, and 9, has lower similarity coefficients $(0.89,0.90$, and 0.91$)$ perhaps owing to chemical inhomogeneities in the glass or to vertical variations within the Nomlaki Tuff Member, even though this unit appears to be texturally homogeneous. An alternative explanation is that the greater differences may result from inadequate separation of crystalline material from the glass, as sample 5 was one of the earlier samples processed in these studies (Sarna-Wojcicki, 1971; Sims and SarnaWojcicki, 1975; Sarna-Wojcicki, 1976), prior to several improvements in separation techniques.

Samples of the Putah Tuff Member analyzed by neutron activation, 10, 13C, and 13D, are from the type locality (fig. 1), a water-laid, composite unit probably produced by several eruptions within a short

Figure 3. Sumary of correlation of late Cenozic tuffs based on neutron activation analys is of glass. Solid horizontal lines indicate correlation certain; dashed horizontal lines, correlation probable; queries, correlation uncertain. Sample numbers are the same as in figure 1 and tables 3 and 4 . For sources of potassium-argon ages, see Sarna-Wojcicki, (1976). 


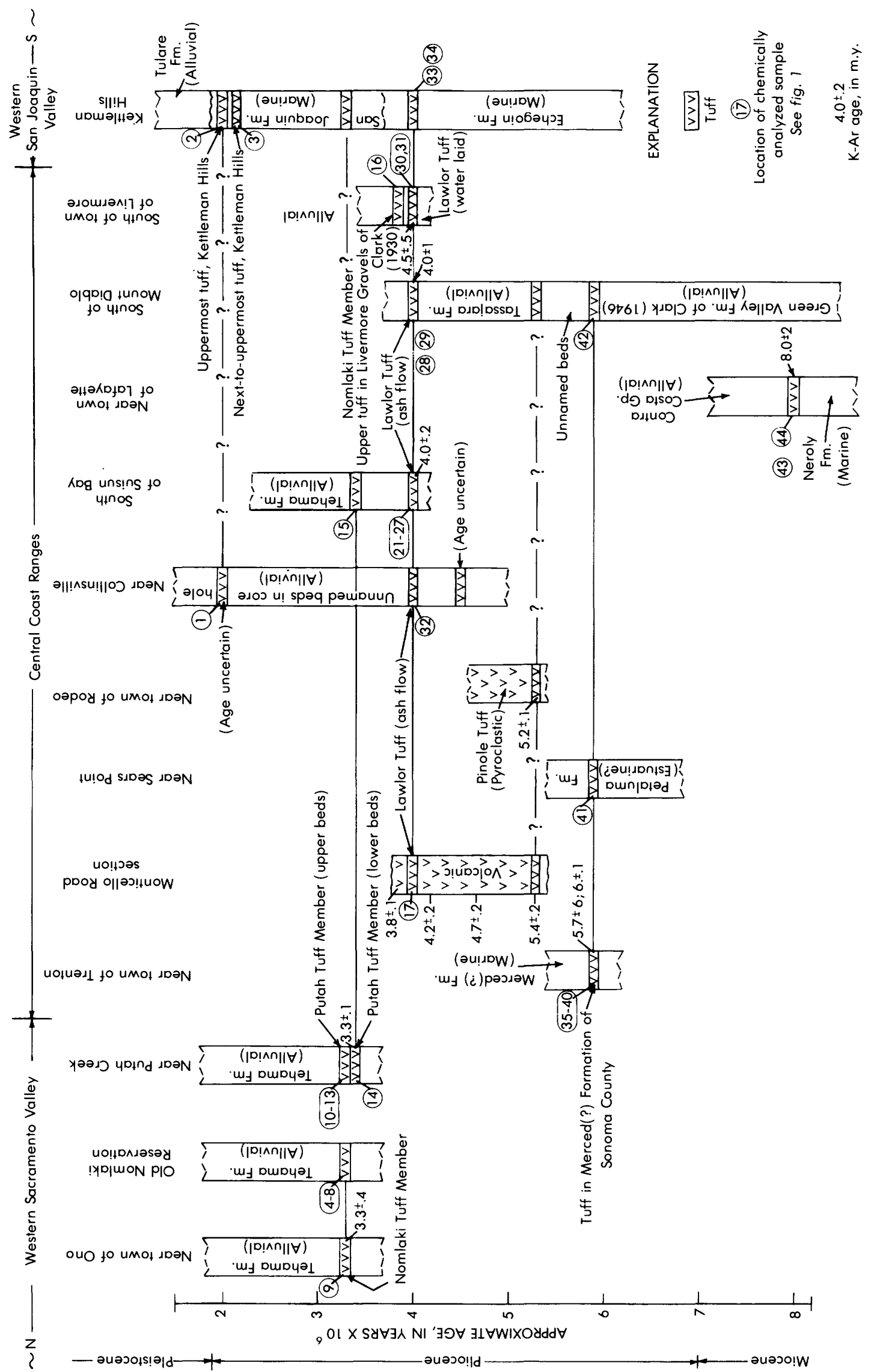




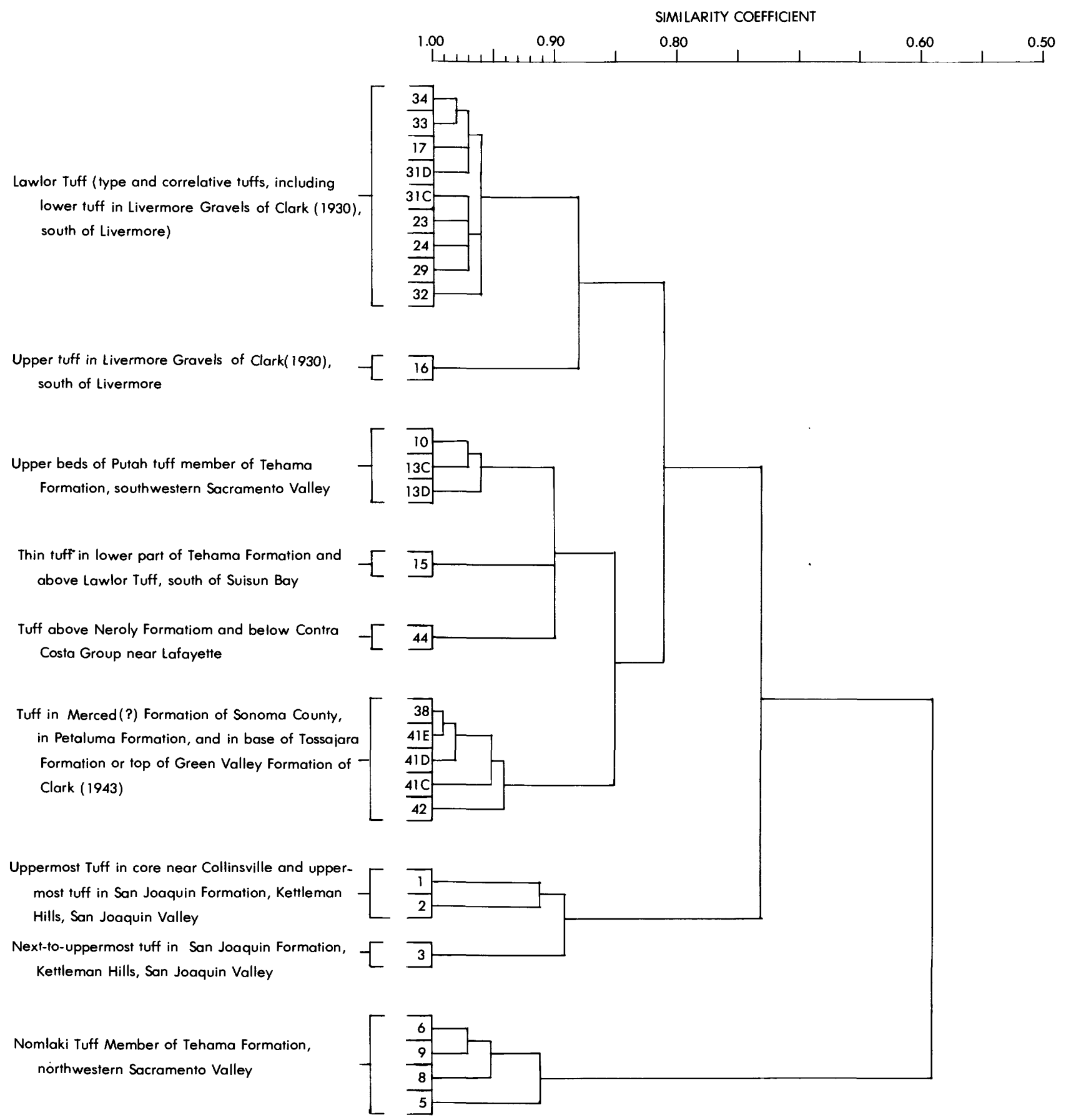

Figure 4.--Similarity coefficient dendrogram. Samples are grouped according to maximum individual values of simi larity coefficients for sample pairs and maximum averages of coefficients for sample groups. 
period. Values of the similarity coefficient of these three samples, all from the upper part of this unit, are $0.97,0.96$, and 0.96 (fig. 4). On the basis of $X$ ray fluorescence analys is of trace and minor elements of the glass and petrographic characteristics (Sims and Sarna-Wojcicki, 1975; Sarna-Wojcicki, 1976), the base of this unit (sample loc. 14) has been correlated with a thin tuff that overlies the Lawlor Tuff south of Suisun Bay (sample 10c. 15, fig. 4). Since analyses by neutron activation have not been made on the basal part of the Putah, comparison of neutron activation and $X$-ray fluorescence analyses cannot be made for these samples.

\section{TUFFS IN UPPERMOST PART \\ OF SAN JOAQUIN FORMATION}

of two thin tuffs (locs. 2 and 3 , fig. 1) in the uppermost part of the San Joaquin Formation in the Kettleman Hills, Kings County, the upper tuff (10c. 2) is chemically similar to a tuff (1oc. 1) found in a core near Collinsville, Solano Countv, at a depth of $184 \mathrm{~m}$ below the surface (courtesy of Douglas Hamilton, Earth Science Associates). Sample 1 is more similar to sample 2 than to sample 3 (similarity coefficient $0.91,0.86)$, but as similar to sample 3 as the two thin tuffs (samples 2 and 3) are to each other (similarity coefficient 0.91). These values of the similarity coefficient are too low to permit a definitive statement on the correlation of these units, but the similar stratigraphic position (above the Lawlor Tuff) of the tephra at both localities, combined with the unusual trace- and minor-element composition of the glass /high content of iron, manganese, zinc, europium, terbium, dysprosium, ytterbium and hafnium, table 3) suggests the possibility of a correlation between samples 1 and 2 .

\section{PROVINCIAL CHEMICAL CHARACTERISTICS}

\section{OF SILICIC TEPHRA}

Analyses of the Nomlaki and Putah Tuff Members of the Tehama Formation illustrate differences between silicic tephra units erupted from different volcanic fields. The Nomlaki Tuff Member (locs. 4-9), situated near the base of the Tehama Formation in northwestern Sacramento Valley, was erupted from a source northeast or east of Sacramento Valley, in the southern Cascade Range volcanic province (Anderson and Russell, 1939; Russe11, 1931; Lydon, 1967). The Putah Tuff Member (locs. 10-14), also in the lower part of the Tehama Formation in southwestern Sacramento Valley, was erupted from a source in the central coast Ranges (Miller, 1966), probably from the Sonoma volcanic field (Sims and Sarna-Wojcicki, 1975; Sarna-Wojcicki, 1976). The large differences in glass chemistry of these two units reflect differences in provenance and differences in the magmas from which the glass was derived. Similarity coefficients between samples of the Nomlaki and Putah Tuff Members range from 0.54 to 0.59 and average a low 0.57 .

Tuffs erupted within the same volcanic field are chemically more similar than those erupted from different fields. Independent evidence regarding the eruptive sources of some of the tuffs can be obtained from observations of changes in their stratigraphic thickness and textural gradients. For example, both the Lawlor Tuff and the Putah Tuff Member were erupted from the Sonoma volcanic field, as inferred from thickening of these units and increase in particle sizes toward this volcanic field. Chemical data from neutron activation analys is supports this interpretation since similarity coefficients between samples of these two tuffs are rather high, averaging 0.81 (fig. 4 ).

Other tuffs erupted in the Sonoma volcanic field, as inferred from physical evidence and glass chemistry, are the tuff (10c. 15) overlying the Lawlor Tuff (loc. 16) south of Livermore Valley, the tuff in the Merced(?) Formation of Sonoma County and its correlative tuffs (locs. 38, 41, 42), and the tuff overlying the Neroly formation and underlying the Contra Costa Group near the town of Lafayette (loc. 44). The two thin tuffs near the top of the San Joaquin Formation in the Kettleman Hills (locs. 1 and 2) are more similar to the tuffs erupted from the Sonoma Volcanic field (similarity coefficients of 0.61 to 0.83 ) than to the Nomlaki Tuff Member (similarity coefficients of 0.48 to 0.54 ) and probably have been derived from this volcanic field.

\section{COMPARISON OF ANALYSES BY X-RAY} FLUORESCENCE AND NEUTRON ACTIVATION

A comparison of element concentrations determined by both neutron activation and X-ray fluorescence analyses for the same samples shows barium, rubidium, and zinc concentrations to be fairly similar, but 1 arge discrepancies exist for iron and manganese, both elements being consistently higher in the $X-r$ ay fluorescence analyses. These differences may be due to differences in standards or absorption corrections used in the two analytical procedures. (Absorption corrections were not used for iron and manganese in $X$ ray fluorescence analysis, since bulk compositions of samples and standards were approximately the same; Sarna-Wojcicki, 1971, 1976). Linear regression analyses indicate that best correspondence between $X$ ray fluorescence and neutron activation analyses was obtained for iron (correlation coefficient $r_{2}^{2}$ of 0.98 ) followed by rubidium, barium, and zinc ( $r^{2}$ of 0.95 , 0.95 , and 0.92 , respectively). Greater scatter of data was found for analyses of manganese $\left(r^{2}\right.$ of 0.82$)$.

Although absolute concentrations of iron, manganese, and, to a lesser extent, rubidium differ between splits of the same samples, relative differences are about the same, and correlations based on neutron activation analyses are essentially the same as those based on X-ray fluorescence analyses. Somewhat better discrimination between units was obtained using neutron activation analysis, probably because a greater number of elements were analyzed and greater precision is obtained for some elements, permitting discrimination between chemically similar tuffs in stratigraphic proximity, for example, samples 
Table 4.--Chemical analyses by X-ray fluorescence

[Sample numbers same as locality numbers in figure 1. Concentrations of $\mathrm{Fe}$ in percent; all others in parts per million. Samples with letter designations $(A, B)$ are replicate analyses of samples from a single locality or of splits of the same sample. X-ray fluorescence data from Sarna-Wojcicki (1976). See table 2 for analytical error for these elements.]

Sample

No. $\mathrm{Ti} \quad \mathrm{Mn}$ Fe $\mathrm{Zn} \quad \mathrm{Rb} \quad \mathrm{Sr} \quad \mathrm{Y} \quad \mathrm{Zr} \quad \mathrm{Ba}$

Nomlaki Tuff Member of Tehama Formation

\begin{tabular}{rrrrrrrrrr}
\hline 4 & 1332 & 419 & 0.94 & 33 & 107 & 169 & 12 & 182 & 1055 \\
15 & 1372 & 518 & .90 & 28 & 102 & 177 & 9 & 169 & 1052 \\
16 & 1168 & 387 & .87 & 28 & 103 & 162 & 14 & 181 & 965 \\
7 & 1453 & 420 & 1.08 & 32 & 99 & 158 & 9 & 151 & 1003
\end{tabular}

Upper beds of Putah Tuff Member of Tehama Formation

\begin{tabular}{rlllllllll}
\hline 11 & 1131 & 244 & 1.40 & 37 & 158 & 68 & 24 & 263 & 981 \\
12 & 1251 & 278 & 1.36 & 45 & 153 & 27 & 28 & 276 & 814 \\
13 & 1088 & 262 & 1.34 & 43 & 174 & 35 & 27 & 256 & 794
\end{tabular}

Lower beds of Putah Tuff Member of the Tehama Formation, and thin tuff in lower part of Tehama Formation, south of Suisun Bay

\begin{tabular}{rlllllllll}
\hline 14 & 1018 & 244 & 1.39 & 39 & 170 & 37 & 21 & 261 & 838 \\
115 & 1006 & 247 & 1.44 & 41 & 186 & 38 & 17 & 274 & 875 \\
\hline
\end{tabular}

Upper tuff in Livermore Gravels of Clark (1930) south of Livermore Valley

\begin{tabular}{llllllllll}
\hline${ }^{1} 16 \mathrm{~A}$ & 1136 & 502 & 1.82 & 60 & 135 & 74 & 23 & 306 & 684 \\
${ }^{1} 16 \mathrm{~B}$ & 1137 & 517 & 1.82 & 56 & 137 & 82 & 24 & 290 & 718
\end{tabular}

16 and 31C, D (fig. 2). Precision for analyses of titanium, zirconium, strontium, and yttrium, elements useful in correlation of silicic tephra, is greater in $X$-ray fluorescence than in neutron activation analysis.

\section{REFERENCES CITED}

Anderson, C. A., and Russe11, R. D., 1939, Tertiary formations of northern Sacramento Valley, California: California Journal of Mines and Geology, v. 35, no. 3, p. 219-253.

Bartow, J. A., Sarna-Wojcicki, A. M., Addicott, w. 0., and Lajoie, K. R., 1973, Correlation of marine and continental pliocene deposits in northern California by tephrochronology [abs.]: American Association of Petroleum Geologists Bulletin, v.
57 , no. 4, p. 769 .
Table 4.--Continued.

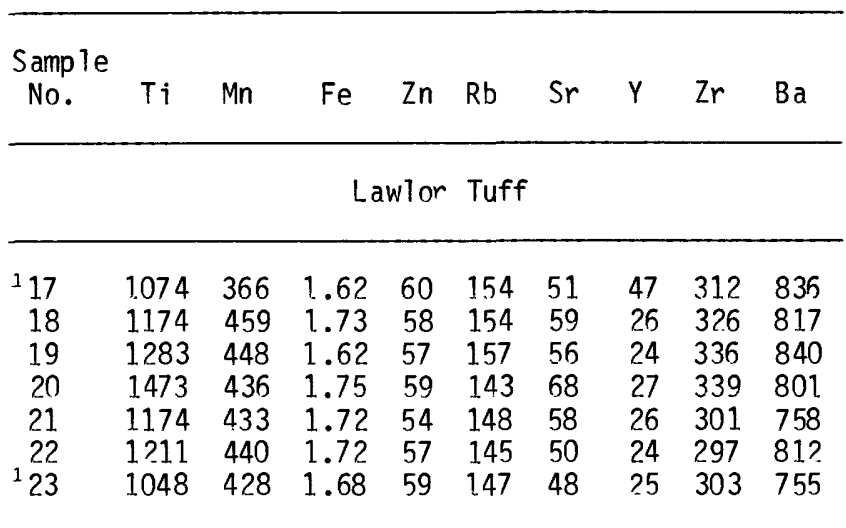

Tuff in the Merced(?) Formation of Sonoma Countv, in Petaluma Formation, and in lower part of Tassajara Formation or top of Green Valley Formation of Clark (1943)

\begin{tabular}{rrrlllllll}
\hline${ }^{1} 24$ & 1180 & 470 & 1.81 & 53 & 149 & 62 & 25 & 304 & 796 \\
25 & 1203 & 447 & 1.78 & 56 & 152 & 62 & 25 & 326 & 845 \\
26 & 1173 & 437 & 1.73 & 59 & 143 & 54 & 18 & 329 & 830 \\
27 & 1129 & 454 & 1.72 & 56 & 146 & 57 & 18 & 319 & 768 \\
27 & 1258 & 456 & 1.68 & 57 & 144 & 71 & 32 & 313 & 913 \\
28 & 1183 & 449 & 1.83 & 61 & 148 & 53 & 24 & 304 & 849 \\
${ }^{1} 29$ & 1134 & 422 & 1.70 & 59 & 148 & 71 & 29 & 305 & 809 \\
30 & 1134 & 40 & 140 \\
${ }^{1} 31$ & 1213 & 431 & 1.75 & 58 & 143 & 60 & 25 & 297 & 733 \\
35 & 876 & 237 & 1.18 & 40 & 181 & 41 & 24 & 247 & 686 \\
36 & 803 & 233 & 1.18 & 43 & 176 & 39 & 21 & 242 & 698 \\
37 & 710 & 250 & 1.21 & 40 & 174 & 40 & 19 & 216 & 759 \\
${ }^{1} 38$ & 766 & 259 & 1.13 & 44 & 190 & 28 & 28 & 225 & 817 \\
39 & 750 & 310 & 1.09 & 44 & 179 & 27 & 24 & 249 & 751 \\
40 & 755 & 285 & 1.11 & 48 & 183 & 27 & 28 & 228 & 755 \\
${ }^{1} 41 \mathrm{~A}$ & 729 & 278 & 1.07 & 41 & 181 & 44 & 23 & 221 & 724 \\
${ }^{1} 41 \mathrm{~B}$ & 775 & 21.5 & 1.16 & 48 & 177 & 29 & 29 & 219 & 767 \\
${ }^{1} 42$ & 738 & 240 & 1.16 & 39 & 179 & 59 & 20 & 261 & 667 \\
& & & & & & & & & \\
\hline
\end{tabular}

Tuff above Neroly Formation and below the Contra Costa Group, near Lafayette

$\begin{array}{llllllllll}43 & 857 & 250 & 1.27 & 46 & 169 & 39 & 41 & 279 & 654\end{array}$

${ }^{1}$ Sample analyzed by both neutron activation and X-ray fluorescence.

Borchardt, G. A., Aruscavage, P. J., and Millard, H. T., Jr., 1972, Correlation of the Bishop ash, a Pleistocene marker bed, using instrumental neutron activation analysis: Journal of Sedimentary Petrology, v. 42, no. 2, p. 301-306.

Bowman, H. W., Asaro, Frank, and Perlman, Isidore, 1973, On the uniformity of composition in obsidian and evidence for magmatic mixing: Journal of Geology, v. 81, no. 3, p. 312-327. 
Carmichael, I. S. E., Hempel, Joachim, and Jack, R. N., 1968, Analytical data on the U.S.G.S. standard rocks: Chemical Geology, v. 3, p. 59-64.

Clark, B. L., 1930, Tectonics of the Coast Ranges of middle California: Geological Society of America Bulletin, v. 41 , no. 4, p. 747-828.

Clark, B. L., 1943, Notes on California Tertiary correlation, in Geologic formations and economic development of the oil and gas fields of California: California Division of Mines Bulletin 118 , p. 187-191.

Czamanske, G. K., and Porter, S. C., 1965, Titanium dioxide in pyroclastic layers from volcanoes in the Cascade Range: Science, v. 150, no. 3699, p. 10221025.

Dudas, M. J., Harward, M. E., and Schmitt, R. A., 1973, Identification of dacitic tephra by activation analysis of their primary mineral phenocrysts: Quaternary Research, v. 3, p. 307315.

Evernden, J. F., Savage, D. E., Curtis, G. H., and James, G. T., 1964, Potassium-argon dates and the Cenozoic mammalian chronology of North America: American Journal of Science, v. 262, p. 145-198.

Flanagan, F. J., 1969, Survey standards--II, First compilation of data for the new U.S.G.S. rocks: Geochimica et Cosmochimica Acta, v. 33, p. 81-120.

Flanagan, F. J., 1973, 1972 values for international geochemical reference samples: Geochimica et Cosmochimica Acta, v. 37, p. 1189-1200.

Fleischer, Michael, 1969, U.S. Geological Survey standards--I, Additional data on rocks $G-1$ and $W-1$, 1965-1967: Geochimica et Cosmochimica Acta, v. 33, p. 65-79.

Huey, A. S., 1948, Geology of the Tesla quadrangle, California: California Division of Mines Bulletin $140,75 \mathrm{p}$

Izett, G. A., Wilcox, R. E., Powers, H. A., and Desborough, G. A., 1970, The Bishop ash bed, a Pleistocene marker bed in the western United States: Quaternary Research, v. 1, p. 121-132.

Jack, R. N., and Carmichael, I. S. E., 1968, The chemical "fingerprinting" of acid volcanic rocks: California Division of Mines Special Report 100, p. 17-32.

Jack, R. N., Lajoie, K. R., and Carmichael, I. S. E., 1968 "Fingerprinting" of obsidian and pumice from the western United States [abs.]: Geological Society of America Special Paper 115, p. 107.

Jennings, C. W., and Burnett, J. L., 1961, Geological map of California, San Francisco sheet: California Division of Mines and Geology, scale 1:250,000.

Koenig, J. B., 1963, Geologic map of California, Santa Rosa sheet: California Division of Mines and Geology, scale 1:250,000.

Lajoie, K. R., and Carmichael, I. S. E., 1968, Late Pleistocene and Recent volcanism in the Mono Basin abs. : Geological Society of America Special Paper 115, p. 127
Lydon, P. A., 1967, The origin of Tuscan Buttes and the volume of the Tuscan Formation in northern California, in Short contributions to California geology: CaTifornia Division of Mines Special Report 91, p. 17-26.

Miller, W. L., 1966, Petrology of the Putah Tuff Member of the Tehama Formation, Yolo and Solano Counties, California: Davis, University of California, M. S. thesis, $85 \mathrm{p}$.

Oestreich, E. S., 1958, Geology of the Tassajara quadrangle: Berkeley, University of California, M. S. thesis.

Patten, P. R., 1948, The San Pablo Formation north of Mount Diablo, California: Berkeley, University of California, M. S. thesis.

Perlman, Isadore, and Asaro, Frank, 1969, Pottery analys is by neutron activation: Archaeometry, $v$. 11 , p. 21-52.

Randle, Keith, Goles, G. G., and Kittleman, L. R., 1971, Geochemical and petrological characterization of ash samples from Cascade Range volcanoes: Quaternary Research, v. 1, p. 261-282.

Rogers, T. H., 1966, Geological map of California, San Jose sheet: California Division of Mines and Geology, scale 1:250,000.

Russe11, R. D., 1931, The Tehama Formation of northern California: Berkeley, University of California, Ph.D. thesis.

Sarna-Wojcicki, A. M., 1971, Correlation of late Cenozoic pyroclastic deposits in the central Coast Ranges of California: Berkeley, University of California, Ph.D. thesis, $174 \mathrm{p}$.

Sarna-Wojcicki, A. M., 1976, Correlation of late Cenozoic tuffs in the central coast Ranges of California by means of trace- and minor-element chemistry: U.S. Geological Survey Professional Paper 972, 30. p.

Sims, J. D., and Sarna-Wojcicki, A. M., 1975, New and revised stratigraphic names in the western Sacramento Valley, California, in Changes in stratigraphic nomenclature by the U.S. Geological Survey, 1973: U.S. Geological Survey Bulletin 1395-A, p. A50-A55.

Strand, R. G., and Koenig, J. B., 1965, Geologic map of California, Sacramento sheet: California Division of Mines and Geology, scale 1:250,000.

Travis, R. B., 1952, Geology of the Sebastopol quadrangle, California: California Division of Mines Bulletin 162, 33 p.

Weaver, C. E., 1949, Geology and mineral deposits of an area north of San Francisco Bay, California: California Division of Mines Bulletin 149, $135 \mathrm{p}$.

Westgate, J. A., and Gold, C. M., 1974, World bibliography and index of Quaternary tephrochronology: Alberta, Canada, Alberta University, $528 \mathrm{p}$.

Woodring, W. P., Stewart, Ralph, and Richards, R. W., 1940, Geology of the Kettleman Hills oil field, California: U.S. Geological Survey Professional Paper 195,170 p. 
